\title{
ANALISIS TARIF ANGKUTAN UMUM BERDASARKAN BIAYA OPERASIONAL KENDARAAN DI KOTA AMBON (STUDI KASUS KONDISI PSBB)
}

\author{
Fuad Hasan Ohorella ${ }^{1, *}$, Imran Oppier ${ }^{2}$ \\ 1Jurusan Perkapalan, Prodi Teknik Sipil, Fakultas Teknik, Universitas Pattimura, Ambon 97233 \\ *Email: fuad24lesta@gmail.com \\ 2Jurusan Perkapalan, Prodi Teknik Sipil, Fakultas Teknik, Universitas Pattimura, Ambon 97233 \\ Email: imranoppier.iwan@gmail.com
}

\begin{abstract}
Abstrak. Angkutan umum antara laut pulau merupakan salah satu tulang punggung (backbone) ekonomi dimana Provinsi Maluku merupakan daerah kepulauan. Kota Ambon sebagai ibukota Propinsi Maluku adalah kota dengan aktivitas dan interaksi antar masyarakat menggunakan Angkutan Umum untuk menunjang kegiatan sehari-hari. Namun dikarenakan Pemberlakukan PSBB (Pembatasan Sosial Berskala Besar) sejak tanggal 23 Juni sampai dengan 22 November 2020 mengakibatkan dibatasinya jumlah angkutan umum (Perwali No. 18), dengan pemberlakuan ganjil genap sampai dengan pembatasan penumpang ( 6 orang per rit), yang mengakibatkan Biaya Operasional Kendaraan akan bertambah. Penelitian ini Bertujuan mengetahui berapa besar penggunaan tarif batas atas dan bawah untuk masyarakat dan mahasiswa. Pada penelitian ini digunakan metode Perhitungan sesuai Standart Direktorat Jenderal Perhubungan Darat (2002) SK 687/AJ.206/DRDJ/2002. Hasil peenlitian menunjukkan Tarif batas atas dan bawah untuk masyarakat pada Kecamatan Nusaniwe Rp 16.592 - Rp 11.061,-; Kecamatan Sirimau Rp 5.138 - Rp 3.425,-; dan Kecamatan Baguala dan Teluk Ambon Rp 25.000 - Rp 16.666,-. Tarif batas atas dan bawah untuk mahasiswa pada Kecamatan Nusaniwe Rp 8.296 - Rp 5.531,-; Kecamatan Sirimau Rp 2.569 - Rp 1.712,-; dan Kecamatan Baguala dan Teluk Ambon Rp 12.500 - Rp 8.333,-. Tarif berdasarkan BOK pada masa pemberlakuan PSBB berkisar antara Rp 25.000 - Rp 5.138,-, sedangkan tarif riel Rp 3.000 - Rp 5.000.
\end{abstract}

Kata Kunci : BOK, Tarif, Trayek.

\begin{abstract}
Public transportation between the island seas is one of the economic backbones where Maluku Province is an archipelagic area. Ambon City as the capital of Maluku Province is a city with activities and interactions between communities using public transportation to support daily activities. However, due to the enactment of PSBB (LargeScale Social Restrictions) from June 23 to November 22, 2020, the number of public transportations (Perwali No. 18) is limited, with odd-even implementations up to passenger restrictions (6 people per trip), resulting in operational costs. Vehicles will increase. This study aims to find out how much the upper and lower limit tariffs are used for the community and students. In this study, the calculation method was used according to the Standards of the Directorate General of Land Transportation (2002) SK 687/AJ.206/DRDJ/2002. The results of the study show that the upper and lower tariff rates for the community in Nusaniwe District are Rp. 16,592 - Rp. 11,061,-; Sirimau District IDR 5,138 - IDR 3,425,-; and Baguala and Teluk Ambon Districts Rp. 25,000 - Rp. 16,666,-- The upper and lower limit rates for students in Nusaniwe District are Rp. 8,296 - Rp. 5,531,-; Sirimau District IDR 2,569 - IDR 1,712,-; and Baguala and Teluk Ambon Districts Rp 12,500 - Rp 8,333,-. Tariffs based on the BOK during the PSBB period ranged from $R p$. 25,000 - Rp. 5,138,-, while the real tariff was $R p$. 3,000 - Rp. 5,000.
\end{abstract}

Keywords: BOK, Tariff, Route. 


\section{PENDAHULUAN}

Kebutuhan akan transportasi timbul dari kebutuhan manusia. Transportasi dapat diartikan sebagai suatu kegiatan yang memungkinkan perpindahan manusia maupun barang, Kota Ambon sebagai Ibukota Propinsi Maluku adalah kota dengan aktivitas dan interaksi antar masyarakat yang kompleks dan bervariasi. Angkutan umum biasanya digunakan oleh masyarakat kota Ambon khususnya masyarakat yang berpenghasilan menengah kebawah, mereka menggunakan angkutan umum untuk menunjang kegiatan sehari-hari sehingga mobilitas jasa angkutan ini dirasakan sangat penting keberadaannya

Pemberlakukan PSBB (Pembatasan Sosial Berskala Besar) di Kota Ambon di mulai dari tanggal 23 juni sampai dengan 22 November 2020 mengakibatkan dibatasinya jumlah angkutan umum (Perwali No. 18), dimulai dengan diberlakukan ganjil genap sampai dengan pembatasan penumpang (6 orang per rit) [1].

Dalam penentuan tarif angkutan salah satu komponen penting adalah BOK. Sehingga dengan mengetahui $\mathrm{BOK}$, seorang pengusaha dapat mengontrol biaya keluar dan masuk dengan mengetahui sub komponen BOK misalnnya harga ban, harga oli, harga BBM, harga filter udara, filter penyaring, harga pelumas, upah sopir, upah kondektur, serta biaya pengeluaran yang diperlukan dalam pemeliharaan kendaraan misalnya biaya servis besar, sevice kecil dan lain sebagainya. Berdasarkan keadaan dilapangan, maka dilakukan penelitian tentang Analsis Biaya Operasional Kendaraan di Kota Ambon [2].

Penelitian ini dilakukan dengan tujuan untuk mengetahui berapa besar tarif batas atas dan bawah berdasarkan BOK untuk Umum dan Mahasiswa.

\section{BAHAN DAN METODE}

\subsection{Pembatasan Berskala Besar (PSBB)}

Dikeluarkannya peraturan Wali Kota (PEWALI) No. 18 tentang PSBB [2], memuai 6 poin penting:

1. Pelaksanaan pembelajaran disekolah dan atau institusi pendidikan lainya.

2. Aktifitas bekerja di tempat kerja.

3. Kegiatan keagamaan di tempat ibadah

4. Kegiatan di tempat umum atau fasilitas umum

5. Kegiatan sisial dan budaya

6. Pergerakan orang dan barang menggunakan moda transportasi.

Dengan fokus pada 6 poin ini, maka penerapan PSBB di Kota Ambon kedepan, akan terlihat apakah ada penurunan aktifitas masyarakat pada tempat umum atau tidak, serta himbauan dan penerapan pada tempat-tempat ibadah, sehingga keseriusan pemerintah dalam jalankan PSBB pun tidak sia-sia.

Dalam pemberlakukan sesuai dengan Perwali No. 18 pada poin 6. Dimana pergerakan orang dan barang menggunakan moda transportasi. Sehingga Plt kepala Dinas Perhubungan menggunakan sistem ganjil genap sampai dengan penggunaan Shif A, B, dan C serta di atur juga tentang jumlah penumpang 6 orang per rit [1].

\subsection{Pengertian Transportasi, Biaya, Angkutan Kota, Penentuan Tarif}

\section{a. Pengertian Transportasi}

Tindakan atau kegiatan mengangkut atau memindahkan muatan (barang dan orang) dari suatu tempat ke tempat lain, atau dari tempat asal ke tempat tujuan Peranan transportasi sangat besar dalam kehidupan masyakat modern. Dipicu oleh upaya untuk mendekatkan jarak [3], [4], [5].

Biaya sebenarnya diketahui ada dua istilah atau terminologi biaya yang perlu mendapat perhatian, yaitu sebagai berikut: 1. Biaya (Costs) yang dimaksud dengan biaya disini adalah semua pengorbanan yang dibutuhkan dalam rangka mencapai suatu tujuan yang diukur dengan nilai uang. 2. Pengeluaran (Expence) yang dimaksud dengan expence ini biasanya yang berkaitan dengan sejumlah uang yang dikeluarkan atau dibayarkan dalam rangka mendapatkan sesuatu hasil yang diharpkan [6], [7].

\section{b. Biaya}

Biaya-biaya yang biasa timbul dalam operasional berbagai bentuk sarana kendaraan ini disebut sebagai biaya operasional kendaraan (BOK) yang terdiri dari: 1. Biaya tergantung jarak yakni biaya yang jumlahnya tergantung jauh dekatnya jarak tempuh, 2. Biaya tergantung kecepatan yakni biaya yang besar kecilnya ditentukan oleh cepat lambatnya kendaraan melaju. Biasanya semakin cepat kendaraan bergerak akan semakin rendah biaya yang dikeluarkan, 3. Biaya tergantung waktu yakni yang besar kecilnya ditentukan oleh waktu operasi. Pedoman Perhitungan Komponen-Komponen Biaya [2], [7].

1. Biaya Langsung
a. Penyusutan kendaraan
b. Bunga modal kendaraan produktif
c. Awak kendaraan

- Gaji/ upah 
- Tunjangan kerja operasi (uang dinas)

- Tunjangan sosial

d. Bahan bakar minyak

e. Ban

f. Service kecil

g. Service besar

h. Pemeriksaan

i. Penembahan oli

j. Suku cadang

k. Cuci kendaraan

1. Restribusi terminal

m. STNK/Pajak

n. Kir

o. Asuransi

- Asuransi kendaraan

- Asuransi awak kendaraan

Tabel 1. Asumsi perhitungan biaya

\begin{tabular}{|c|c|c|c|}
\hline No. & Uraian & Satuan & $\begin{array}{c}\text { Angkutan Kota } \\
\text { Mobil } \\
\text { Penumpang } \\
\text { Umum (MPU) }\end{array}$ \\
\hline 1 & $\begin{array}{l}\text { Masa penyusutan } \\
\text { kendaraan }\end{array}$ & Th & 5 \\
\hline 2 & Jarak tempuh rata-rata & $\mathrm{Km} / \mathrm{hr}$ & 250 \\
\hline 3 & Bahan Bakar Minyak & $\mathrm{Km} / \mathrm{lt}$ & $7.5-9$ \\
\hline 4 & Jarak tempuh ganti ban ${ }^{3)}$ & $\mathrm{Km}$ & 25.000 \\
\hline 5 & Ratio pengemudi/bus & Org/kend & 1.2 \\
\hline 6 & Ratio kondektur/bus & Org/kend & \\
\hline 7 & $\begin{array}{l}\text { Jarak Tempuh antar } \\
\text { service kecil }\end{array}$ & $\mathrm{Km}$ & 4.000 \\
\hline 8 & $\begin{array}{l}\text { Suku cadang/service } \\
\text { besar }\end{array}$ & $\mathrm{Km}$ & 12.000 \\
\hline 9 & $\begin{array}{l}\text { Penggantian minyak } \\
\text { motor }\end{array}$ & $\mathrm{Km}$ & 3.500 \\
\hline 10 & Penggantian minyak rem & $\mathrm{Km}$ & 12.000 \\
\hline 11 & Penggantian Gemuk & $\mathrm{Km} / \mathrm{kg}$ & 4.000 \\
\hline 12 & $\begin{array}{l}\text { Penggantian minyak } \\
\text { gardan }\end{array}$ & $\mathrm{Km}$ & 12.000 \\
\hline 13 & $\begin{array}{l}\text { Penggantian minyak } \\
\text { persneling }\end{array}$ & $\mathrm{Km}$ & 12.000 \\
\hline 14 & Hari jalan siap operasi & $\mathrm{Hr} / \mathrm{th}$ & 365 \\
\hline 15 & SO : SGO & $\%$ & 80 \\
\hline 16 & Nilai residu & $\%$ & - \\
\hline \multicolumn{4}{|c|}{ Sumber : SK. 687/AJ.206/DRJD/2002 } \\
\hline \multicolumn{4}{|c|}{ Catatan } \\
\hline 1) & \multicolumn{3}{|c|}{$\begin{array}{l}\text { Untuk DKI Penggunaan BBM 2,6 km/lt dan di luar DKI } \\
3 \mathrm{~km} / \mathrm{lt}\end{array}$} \\
\hline $\begin{array}{l}\text { 2) } \\
\text { 3) }\end{array}$ & \multicolumn{2}{|c|}{$M P U$ penggunaan $B B M 9 \mathrm{Km} / \mathrm{lt}$} & Daya tempuh ban tergantung koefisien gesek jalan \\
\hline
\end{tabular}

\section{Biaya tidak langsung}

a. Biaya pegawai selain awak kendaraan

- Gaji/ upah

- Uang lembur

- Tunjangan sosial

- Tunjangan perawatan kesehatan

- Pakaian dinas

- Biaya pengelolaan

b. Biaya pengelolaan

- Penyusutan bangunan kantor
- Penyusutan pool dan bengkel

- Penyusutan inventaris/ alat kantor

- Penyusutan sarana bengkel

- Biaya administrasi kantor

- Biaya pemeliharaan kantor

- Biaya pemeliharaan pool dan bengkel

- Biaya listrik dan air

- Biaya telepon dan telegram

- Biaya perjalanan dinas selain awak kendaraan

- Pajak perusahaan

- Izin trayek

- Izin usaha

- Biaya pemasaran

- Lain-lain [2], [7], [8], [9].

\section{Asumsi Perhitungan Biaya}

Untuk melakukan perhitungan biaya pokok, perlu menggunakan pedoman. Pedoman-pedoman sesuai Keputusan Direktur Jenderal Perhubungan Darat Nomor: SK.687/AJ.206/DRJD/2002 Tentang Pedoman Teknis Penyelenggaraan Angkutan Penumpang Umum di Wilayah Perkotaan Dalam Trayek Tetap dan Teratur dapat digunakan sebagai asumsi.

Tabel 2. Kapasitas kendaraan

\begin{tabular}{lcccc}
\hline \multirow{2}{*}{ Jenis Angkutan } & \multicolumn{3}{c}{ Kapasitas kendaraan } & $\begin{array}{c}\text { Kapasitas } \\
\text { Penumpang } \\
\text { Perhari }\end{array}$ \\
\cline { 2 - 5 } & Duduk & Berdiri & Total & \begin{tabular}{c} 
/kendaraan \\
\hline $\begin{array}{l}\text { Mobil } \\
\text { penumpang }\end{array}$
\end{tabular} \\
\hline
\end{tabular}

umum

Sumber: SK Nomor 687/AJ.206/DRJD/2002

\section{c. Angkutan Kota}

Pelayanan angkutan kota dapat diselenggarakan dengan ciri-ciri [2], sebagai berikut:

a) Trayek utama

- Mempunyai jadwal tetap, sebagaimana tercantum dalam jam perjalanan pada kartu pengawasan kendaraan yang dioperasikan.

- Melayani angkutan antar kawasan utama, antara kawasan utama dan pendukung dengan ciri melakukan perjalanan ulangalik secara tetap.

- Pelayanan angkutan secara terus menerus serta berhenti pada tempat-tempat untuk menaikkan dan menurunkan penumpang yang telah ditetapkan untuk angkutan kota

b) Trayek Cabang

- Berfungsi sebagai penunjang terhadap trayek utama.

- Mempunyai jadwal tetap sebagaimana tercantum dalam jam perjalanan pada 
kartu pengawasan kendaraan yangdioperasikan.

- Melayani angkutan pada kawasan pendukung dan antara kawasan pendukung dan permukiman.

- Pelayanan angkutan secara terus menerus serta berhenti pada tempat-tempat untuk menaikkan dan menurunkan punumpang yang telah ditetapkan untuk angkutan kota.

- Melayani angkutan dalam kawasan permukiman.

c) Trayek langsung

- Mempunyai jadwal tetap sebagaimana tercantum dalam jam perjalanan pada kartu pengawasan kendaraan yang dioperasikan.

- Pelayanan angkutan secara terus menerus serta berhenti pada tempat-tempat untuk menaikkan dan menurunkan penumpang yang telah ditetapkan untuk angkutan kota.

- melayani angkutan antara kawasan utama dengan kawasan pendukung dan kawasan permukiman.

\section{d. Penentuan Tarif}

Ada bebererapa item dasar perhitungan tarif sebagai berikut:

a. Biaya pokok atau biaya produksi adalah besaran pengorbanan yang dikeluarkan untuk menghasilkan satu satuan unit produksi jasa angkutan.

b. Tarif angkutan umum penumpang kota merupakan hasil perkalian antara tarif pokok dan jarak (kilometer) rata-rata satu perjalanan (tarif Break Even Point) dan ditambah 10\% untuk jasa keuntungan perusahaan.

c. Faktor muat (load factor) merupakan perbandingan antara kapasitas terjual dan kapasitas tersedia untuk satu perjalanan yang biasa dinyatakan dalam persen (\%). Faktor muat untuk perhitungan tarif umumnya adalah $70 \%$.

d. Satuan produksi adalah pembagi terhadap total biaya produksi, sehingga dapat ditentukan besar per satuan produksi.

e. Alat produksi adalah sarana angkutan yang digunakan untuk memproduksi jasa angkutan penumpang dengan atau tanpa fasilitas tambahan.

f. Rit adalah satu kali perjalanan kendaraan dari tempat asal ke tempat tujuan.

g. Waktu tempuh/ rit adalah lama perjalanan dalam satu rit.

h. Jarak tempuh/ rit adalah jarak $\mathrm{km}$ yang ditempuh dalam satu hari. i. Jarak tempuh/ hari adalah jarak $\mathrm{km}$ yang ditempuh dalam satu hari.

j. Frekuensi adalah jumlah rit dalam kurun waktu tertentu (per jam, per hari).

k. Kapasitas angkut/ kapasitas tersedia adalah kapasitas maksimal yang tersedia untuk penumpang (duduk dan berdiri) sesuai dengan ketentuan yang berlaku.

1. Kapasitas terjual adalah jumlah penumpang yang diangkut dihitung berdasarkan jumlah tempat duduk yang terpakai ditambah berdiri dikalikan frekuensi.

m. Hari operasi per bulan adalah jumlah hari operasi dalam satu bulan.

n. Kilometer-kosong adalah kilometer yang tidak produktif yang terjadi pada awal operasi (berangkat dari pool) dan akhir operasi (kembali ke pool). Kilometer-kosong per hari diasumsikan sebesar 3\% dari total kilometertempuh per hari.

o. Kilometer-efektif adalah kilometer-tempuh produktif pada saat operasi.

p. Seat-km (Pnp-km) tersedia adalah jumlah tempat dudukkm, dihitung dengan mengalikan jumlah tempat duduk yang tersedia dengan frekuensi serta jarak tempuh dari tempat asal ke tempat tujuan [2], [8], [6], [10].

\subsection{Metode Penelitian}

\section{a. Lokasi dan Obyek Penelitian}

Penelitian ini dilakukan di Terminal Mardika Kota Ambon, Toko Onderdil Mobil Kota Ambon, dan Dealer Mobil Kota Ambon.

Subjek penelitian dalam penelitian ini adalah Angkutan Umum di Kota Ambon antara lain: Trayek Kecamatan Nusaniwe, Kecamatan Sirimau, Leitimur Selatan, Kecamatan Baguala, dan Kecamatan Teluk Ambon.

Objek penelitian yang akan ditinjau adalah komponen biaya operasional kendaraan angkutan umum trayek Kecamatan Nusaniwe, Kecamatan Sirimau, Kecamatan Baguala, dan Kecamatan Teluk Ambon.

\section{b. Jenis dan Metode Pengumpulan Data}

Data primer dalam penelitian ini diperoleh dengan cara survey langsung di lapangan, berupa: Melakukan Observasi dan Wawancara di Terminal Mardika, beberapa toko suku cadang dan onderdir, serta dieler mobil di Kota Ambon. Data sekunder dalam penelitian ini diperoleh dari Dinas Perhubungan Kota Ambon dan Badan Pelayanan Perijinan Terpadu Kota Ambon berupa data rute angkutan kota.

Teknik pengumpulan data dengan cara: 1 . Studi pustaka guna memperoleh gambaran teoritis 
mengenai Biaya Operasional Kendaraan (BOK), 2. observasi dan wawancara secara langsung terhadap pegawai kantor Dinas Perhubungan Kota Ambon, pengemudi angkutan umum trayek Kecamatan Nusaniwe, pihak diler mobil, dan toko suku cadang atau toko onderdil kendaraan.

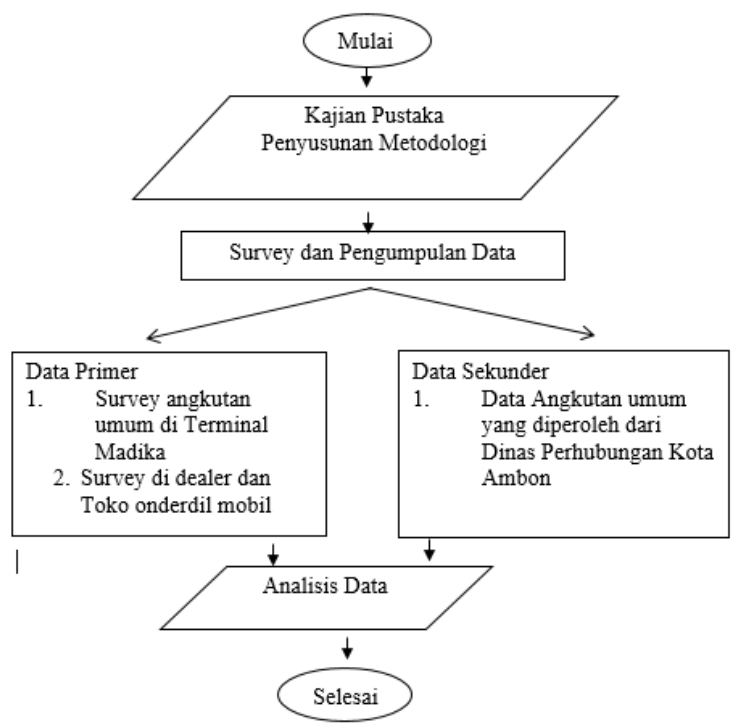

Gambar 1. Bagan alir penelitian

\section{c. Teknik Pengolahan dan Analisis Data}

Teknik pengolahan data dilakukan dengan menggunakan standar perhitungan Dirjen Perhubungan Darat No. SK.687/AJ.206/DRJD/ 2002 untuk memperoleh komponen-komponen yang berkaitan dengan biaya operasional kendaraan. Adapun tahap analisis yang dilakukan, yaitu menganalisis biaya operasi kendaraan (BOK), Tarif Pokok, Tarif BEP, Tarif.

Dengan menggunakan Rumus-rumus sebagai berikut:

\section{a. Tarif}

Tarif $=($ Tarif pokok $x$ jarak rata-rata $)+10 \%$

Tarif $B E P=$ Tarif pokok $x$ jarak rata-rata

Tarif Pokok $=\frac{\text { Total biay a pokok }}{\text { Faktor pengisian } x \text { kapasitas kendaraan }}$

b. Tarif batas atas dan bawah

- Masyarakat

- Batas atas $=120 \% \times$ Tarif

- Batas bawah $=80 \%$ x Tarif

- Mahasiswa

- Batas atas $=50 \% \times$ tarif batas atas masyarakat

- Batas bawah $=50 \% \times$ tarif batas bawah masyarakat [2]

\section{HASIL DAN PEMBAHASAN}

Analisis Trayek Kecamatan Nusaniwe dilakukan berdasarkan SK Dirjen Perhubungan Nomor SK.687/AJ.206/ DRJD/2002 [2].

\subsection{Trayek Kecamatan Baguala dan Teluk Ambon}

Komponen biaya operasi kendaraan ditunjukkan pada Tabel 3.

Tabel 3. Rekapitulasi BOK Kec. Baguala dan Teluk Ambon

\begin{tabular}{|c|c|c|c|c|}
\hline No & Komponen Biaya & \multicolumn{3}{|c|}{ Keterangan } \\
\hline 1 & $\begin{array}{l}\text { Produksi per kendaraan } \mathrm{Km} \text { - } \\
\text { tempuh/hari }\end{array}$ & 185 & & $\mathrm{~km}$ \\
\hline 2 & Biaya Langsung & & & \\
\hline & a. Biaya Penyusutan & $\mathrm{Rp}$ & 530,75 & per kend.km \\
\hline & b. Bunga modal & $\mathrm{Rp}$ & 358,26 & per kend.km \\
\hline & $\begin{array}{l}\text { c. Gaji dan tunjangan } \\
\text { awak kendaraan }\end{array}$ & $\mathrm{Rp}$ & 23,38 & per kend.km \\
\hline & d. BBM & $\mathrm{Rp}$ & 775,24 & per kend.km \\
\hline & e. Ban & $\mathrm{Rp}$ & 64,53 & per kend.km \\
\hline & f. Service kecil & $\mathrm{Rp}$ & 150,81 & per kend.km \\
\hline & g. Service besar & $\mathrm{Rp}$ & 65,01 & per kend.km \\
\hline & $\begin{array}{l}\text { h. Pemeriksaan Umum } \\
\text { (General Overhoul) }\end{array}$ & $\mathrm{Rp}$ & 38,30 & per kend.km \\
\hline & i Over Houl body & $\mathrm{Rp}$ & 70,48 & per kend.km \\
\hline & j Penambahan Oli Mesin & $\mathrm{Rp}$ & 49,32 & per kend.km \\
\hline & k Cuci Kendaraan & $\mathrm{Rp}$ & 81,07 & per kend.km \\
\hline & 1 Retribusi Terminal & $\mathrm{Rp}$ & 27,02 & per kend.km \\
\hline & $\begin{array}{ll}\mathrm{m} & \begin{array}{l}\text { STNK / Pajak } \\
\text { Kendaraan }\end{array}\end{array}$ & $\mathrm{Rp}$ & 16,59 & per kend.km \\
\hline & $\mathrm{n} \quad \mathrm{KIR}$ & $\mathrm{Rp}$ & 12,13 & per kend.km \\
\hline & o Asuransi & $\mathrm{Rp}$ & 82,93 & per kend.km \\
\hline & Jumlah & $\mathrm{Rp}$ & $2.345,82$ & per kend.km \\
\hline 3 & Biaya Tidak Langsung & & & \\
\hline & $\begin{array}{l}\text { a. Biaya Gaji Pegawai Non } \\
\text { Awak Kendaraan }\end{array}$ & $\mathrm{Rp}$ & - & \\
\hline & b. Biaya Pengelolaan & $\mathrm{Rp}$ & 19,05 & per kend.km \\
\hline & Jumlah & $\mathrm{Rp}$ & 19,05 & per kend.km \\
\hline 4 & Biaya Pokok & & & \\
\hline & a. Biaya Langsung & $\mathrm{Rp}$ & $2.345,82$ & per kend.km \\
\hline & b. Biaya Tidak Langsung & $\mathrm{Rp}$ & 19,05 & per kend.km \\
\hline & Jumlah & $\mathrm{Rp}$ & $2.364,88$ & per kend.km \\
\hline 5 & BIAYA POKOK/PNP-KM & $\mathrm{Rp}$ & 394,15 & $/ \mathrm{Pnp} / \mathrm{Km}$ \\
\hline
\end{tabular}

Dari analisis biaya operasi kendaraan Laha diatas, didapat biaya pokok sebesar Rp 394,14 per penumpang-km, maka dapat dihitung posisi biaya operasi kendaraan berdasar faktor muat penumpang. Hal ini dapat diuraikan pada Tabel 4.

Tabel 4. Posisi biaya pada tingkat muat

\begin{tabular}{cc}
\hline Faktor Muat Penumpang & Biaya Operasional Kendaraan \\
\hline $70 \%$ & $\operatorname{Rp~563,07}$ \\
\hline
\end{tabular}

Sesuai SK Nomor 687/AJ.206/DRJD/2002, tarif angkutan umum yang digunakan adalah pada tingkat faktor muat 70\%. Dari Tabel 4, pada tingkat faktor muat $70 \%$ biaya operasi kendaraan trayek Laha di Kota Ambon sebesar Rp 563,07 per penumpang-km. Berdasarkan Tabel 4, dapat dihitung tarif, hal ini dapat di uraikan sesuai Tabel 5 . 
Tabel 5. Tarif trayek Laha

\begin{tabular}{|c|c|c|c|c|c|c|c|c|}
\hline \multirow{2}{*}{ No } & \multirow{2}{*}{$\begin{array}{l}\text { Nama } \\
\text { Trayek }\end{array}$} & \multirow{2}{*}{ Tarif Pokok } & \multirow{2}{*}{ Tarif BEP } & \multirow{2}{*}{ Tarif } & \multicolumn{2}{|c|}{ Masyarakat } & \multicolumn{2}{|c|}{ Mahasiswa } \\
\hline & & & & & Batas Atas & Batas Bawah & Batas Atas & Batas Bawah \\
\hline 1. & Laha & Rp 63,07 & Rp 0.833 & Rp 20.834 & Rp 5.000 & Rp 6.667 & Rp 2.500 & $\mathrm{Rp} 8.333$ \\
\hline
\end{tabular}

Tarif hasil perhitungan sesuai SK Nomor K.687/AJ.206/DRJD/2002 adalah Rp 20.833- per penumpang-km. Tarif tersebut merupakan tarif Break Even Point (BEP) yang diambah $10 \%$ dari tarif BEP sehingga kelebihan $10 \%$ dianggap sebagai keuntungan operator. Oleh karena itu, tarif batas atas dan batas bawah untuk penumpang umum Rp 25.000,-, 16.667,-, sedangkan untuk mahasiswa batas atas dan bawah berkisar $\mathrm{Rp}$ 12,500-, 8.333,-. Dengan demikian hasil rekapan Analisis BOK dapat dilihat pada Gambar 2 dan 3.

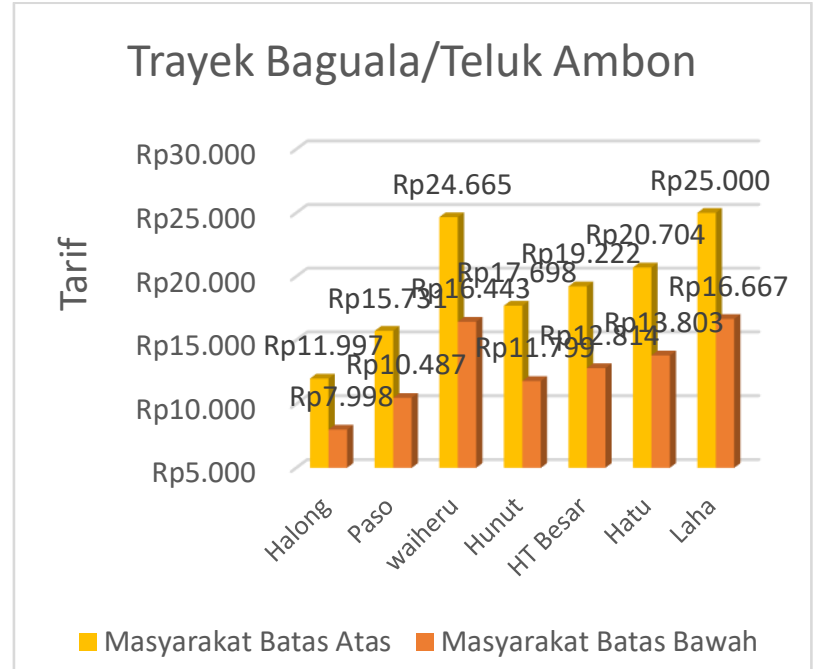

Gambar 2. Grafik rekapitulasi tarif untuk masyarakat

\section{Trayek Baguala/Teluk Ambon}

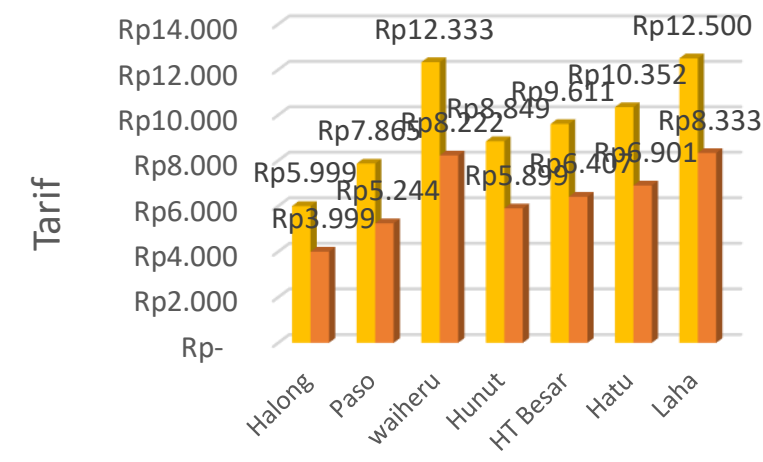

Mahasiswa Batas Atas Mahasiswa Batas Bawah

Gambar 3. Grafik rekapitulasi tarif untuk pelajar/mahasiswa

\subsection{Trayek Kecamatan Nusaniwe}

Tabel 6. Rekapitulasi BOK Kec. Nusaniwe

\begin{tabular}{|c|c|c|c|c|}
\hline No & Komponen Biaya & \multicolumn{3}{|c|}{ Keterangan } \\
\hline 1 & $\begin{array}{l}\text { Produksi per kendaraan } \mathrm{Km} \text { - } \\
\text { tempuh/hari }\end{array}$ & & 36 & $\mathrm{~km}$ \\
\hline \multirow[t]{17}{*}{2} & Biaya Langsung & & & \\
\hline & a. Biaya Penyusutan & $\mathrm{Rp}$ & 654,57 & per kend.km \\
\hline & b. Bunga modal & $\mathrm{Rp}$ & 441,83 & per kend.km \\
\hline & $\begin{array}{l}\text { c. Gaji dan tunjangan } \\
\text { awak kendaraan }\end{array}$ & $\mathrm{Rp}$ & 64,09 & per kend.km \\
\hline & d. BBM & $\mathrm{Rp}$ & $1.009,39$ & per kend.km \\
\hline & e. Ban & $\mathrm{Rp}$ & 64,53 & per kend.km \\
\hline & f. Service kecil & $\mathrm{Rp}$ & 150,81 & per kend.km \\
\hline & g. Service besar & $\mathrm{Rp}$ & 54,26 & per kend.km \\
\hline & $\begin{array}{l}\text { h. Pemeriksaan Umum } \\
\text { (General Overhoul) }\end{array}$ & $\mathrm{Rp}$ & 38,30 & per kend.km \\
\hline & Over Houl body & $\mathrm{Rp}$ & 70,48 & per kend.km \\
\hline & Penambahan Oli Mesin & $\mathrm{Rp}$ & 60,82 & per kend.km \\
\hline & Cuci Kendaraan & $\mathrm{Rp}$ & 99,98 & per kend.km \\
\hline & Retribusi Terminal & $\mathrm{Rp}$ & 33,33 & per kend.km \\
\hline & $\begin{array}{ll}\text { m } & \begin{array}{l}\text { STNK / Pajak } \\
\text { Kendaraan }\end{array}\end{array}$ & $\mathrm{Rp}$ & 20,46 & per kend.km \\
\hline & KIR & $\mathrm{Rp}$ & 14,95 & per kend.km \\
\hline & o Asuransi & $\mathrm{Rp}$ & 102,28 & per kend.km \\
\hline & Jumlah & $\mathrm{Rp}$ & $2.880,09$ & per kend.km \\
\hline \multirow[t]{5}{*}{3} & Biaya Tidak Langsung & & & \\
\hline & a. Biaya Gaji Pegawai Non & & & \\
\hline & Awak Kendaraan & $\mathrm{Rp}$ & - & \\
\hline & b. Biaya Pengelolaan & $\mathrm{Rp}$ & 23,50 & \\
\hline & Jumlah & $\mathrm{Rp}$ & 23,50 & per kend.km \\
\hline \multirow[t]{4}{*}{4} & Biaya Pokok & & & \\
\hline & a. Biaya Langsung & $\mathrm{Rp}$ & $2.880,09$ & \\
\hline & b. Biaya Tidak Langsung & $\mathrm{Rp}$ & 23,50 & \\
\hline & Jumlah & $\mathrm{Rp}$ & $2.903,59$ & \\
\hline 5 & BIAYA POKOK/PNP-KM & $\mathrm{Rp}$ & 483,93 & $/ \mathrm{Pnp} / \mathrm{Km}$ \\
\hline
\end{tabular}

Dari analisis biaya operasi kendaraan Latuhalat diatas, didapat biaya pokok sebesar Rp 483,93 per penumpang-km, maka dapat dihitung posisi biaya operasi kendaraan berdasar faktor muat penumpang. Hal ini dapat diuaraikan pada Tabel 7.

Tabel 7. Posisi biaya pada tingkat muat

\begin{tabular}{|c|c|}
\hline Faktor Muat Penumpang & Biaya Operasional Kendaraan \\
\hline $70 \%$ & $\begin{array}{ll}\mathrm{Rp} & 691,33 \\
\end{array}$ \\
\hline
\end{tabular}

Sesuai SK Nomor 687/AJ.206/DRJD/2002, tarif angkutan umum yang digunakan adalah pada tingkat faktor muat 70\%. Dari tabel 7, pada tingkat faktor muat $70 \%$ biaya operasi kendaraan trayek Latu Lahat di Kota Ambon sebesar Rp 691,33 per penumpang-km.. Dari hasil tabel diatas kita dapat menghitung tarif, hal ini diuraikan pada Tabel 8 . 
Tabel 8. Tarif trayek Latuhalat

\begin{tabular}{ccccccccc}
\hline No & $\begin{array}{c}\text { Nama } \\
\text { Trayek }\end{array}$ & Tarif Pokok & Tarif BEP & Tarif & \multicolumn{2}{c}{ Masyarakat } & \multicolumn{2}{c}{ Mahasiswa } \\
Batas Atas & Batas Bawah & Batas Atas & Batas Bawah \\
\hline 1 & Latuhalat & Rp 691 & Rp 13.827 & Rp 3.827 & Rp 6.592 & Rp 1.061 & Rp 8.296 & Rp 5.531 \\
\hline
\end{tabular}

Tarif hasil perhitungan sesuai SK Nomor K.687/AJ.206/DRJD/2002 adalah Rp 13.827,- per penumpang-km. Tarif tersebut merupakan tarif Break Even Point (BEP) yang diambah $10 \%$ dari tarif BEP sehingga kelebihan 10\% dianggap sebagai keuntungan operator. Oleh karena itu, tarif batas atas dan batas bawah untuk penumpang umum $\mathrm{Rp} 16.592,-$ dan Rp 11.061,-- sedangkan untuk mahasiswa batas atas dan bawah berkisar $\mathrm{Rp}$ 8.296,-sampai Rp 5.531,-. Dengan demikian hasil rekapan Analisis BOK dapat dilihat pada Gambar 4 dan 5.

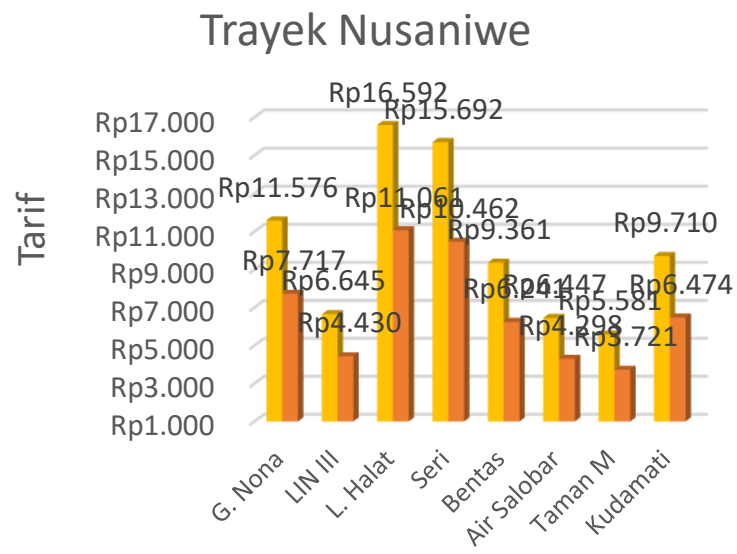

Masyarakat Batas Atas Masyarakat Batas Bawah

Gambar 4. Grafik rekapitulasi tarif untuk masyarakat

\section{Trayek Nusaniwe}

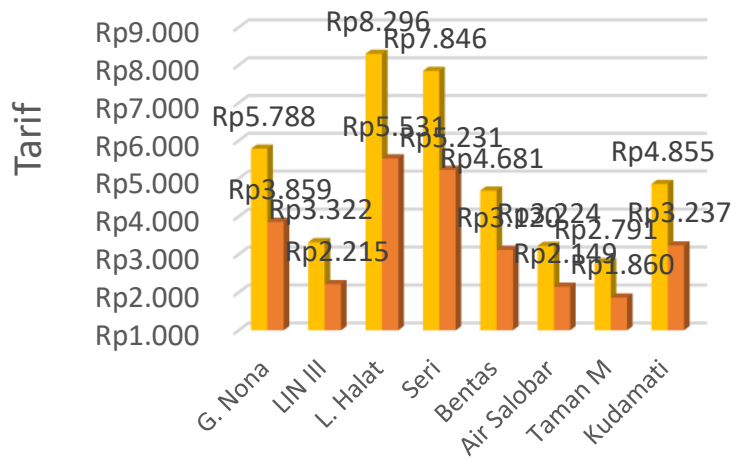

Mahasiswa Batas Atas Mahasiswa Batas Bawah

\subsection{Trayek Kecamatan Sirimau}

Tabel 9. Rekapitulasi BOK Kec. Sirimau

\begin{tabular}{|c|c|c|c|c|}
\hline \multirow{2}{*}{$\frac{\text { No }}{1}$} & \multirow{2}{*}{\begin{tabular}{l}
\multicolumn{1}{c}{ Komponen Biaya } \\
Produksi per kendaraan \\
Km-tempuh/hari
\end{tabular}} & \multicolumn{3}{|c|}{ Keterangan } \\
\hline & & \multirow{2}{*}{\multicolumn{2}{|c|}{32}} & \multirow[t]{2}{*}{$\mathrm{km}$} \\
\hline 2 & Biaya Langsung & & & \\
\hline & a. Biaya Penyusutan & $\mathrm{Rp}$ & 948,57 & per kend.km \\
\hline & b. Bunga modal & $\mathrm{Rp}$ & 640,28 & per kend.km \\
\hline & $\begin{array}{l}\text { c. Gaji dan tunjangan } \\
\text { awak kendaraan }\end{array}$ & $\mathrm{Rp}$ & 61,92 & per kend.km \\
\hline & d. BBM & $\mathrm{Rp}$ & $1.446,19$ & per kend.km \\
\hline & e. Ban & $\mathrm{Rp}$ & 64,53 & per kend.km \\
\hline & f. Service kecil & $\mathrm{Rp}$ & 150,81 & per kend.km \\
\hline & g. Service besar & $\mathrm{Rp}$ & 60,68 & per kend.km \\
\hline & $\begin{array}{l}\text { h. Pemeriksaan Umum } \\
\text { (General Overhoul) }\end{array}$ & $\mathrm{Rp}$ & 38,30 & per kend.km \\
\hline & i Over Houl body & $\mathrm{Rp}$ & 70,48 & per kend.km \\
\hline & $\begin{array}{l}\text { j Penambahan Oli } \\
\text { Mesin }\end{array}$ & $\mathrm{Rp}$ & 88,14 & per kend.km \\
\hline & k Cuci Kendaraan & $\mathrm{Rp}$ & 144,89 & per kend.km \\
\hline & $1 \quad$ Retribusi Terminal & $\mathrm{Rp}$ & 48,30 & per kend.km \\
\hline & $\begin{array}{ll}\mathrm{m} & \begin{array}{l}\text { STNK / Pajak } \\
\text { Kendaraan }\end{array}\end{array}$ & $\mathrm{Rp}$ & 29,64 & per kend.km \\
\hline & n $\quad$ KIR & $\mathrm{Rp}$ & 21,67 & per kend.km \\
\hline & o Asuransi & $\mathrm{Rp}$ & 148,21 & per kend.km \\
\hline & Jumlah & $\mathrm{Rp}$ & $3.962,61$ & per kend.km \\
\hline 3 & Biaya Tidak Langsung & & & \\
\hline & a. Biaya Gaji Pegawai & & & \\
\hline & Non Awak Kendaraan & $\mathrm{Rp}$ & - & \\
\hline & b. Biaya Pengelolaan & $\mathrm{Rp}$ & 34,05 & \\
\hline & Jumlah & $\mathrm{Rp}$ & 34,05 & per kend.km \\
\hline 4 & Biaya Pokok & & & \\
\hline & a. Biaya Langsung & $\mathrm{Rp}$ & $3.962,61$ & \\
\hline & b. Biaya Tidak Langsung & $\mathrm{Rp}$ & 34,05 & \\
\hline & Jumlah & $\mathrm{Rp}$ & $3.996,66$ & \\
\hline 5 & BIAYA POKOK/PNP-KM & $\mathrm{Rp}$ & 666,11 & $/ \mathrm{Pnp} / \mathrm{Km}$ \\
\hline
\end{tabular}

Dari analisis biaya operasi kendaraan Karpan diatas, didapat biaya pokok sebesar Rp 483,93 per penumpang-km, maka dapat dihitung posisi biaya operasi kendaraan berdasar faktor muat penumpang. Hal ini dapat diuaraikan pada Tabel 10.

Tabel 10. Posisi biaya pada tingkat muat

\begin{tabular}{cc}
\hline Faktor Muat Penumpang & Biaya Operasional Kendaraan \\
\hline $70 \%$ & $\operatorname{Rp~} 951,59$ \\
\hline
\end{tabular}

Sesuai SK Nomor 687/AJ.206/DRJD/2002, tarif angkutan umum yang digunakan adalah pada tingkat faktor muat $70 \%$. Dari Tabel 10, pada tingkat faktor muat $70 \%$ biaya operasi kendaraan trayek Karpan di Kota Ambon sebesar Rp 951,59 per penumpang-km. Dengan demikian, dapat dihitung tarif, sebagaimana Tabel 11.

Gambar 5. Grafik rekapitulasi tarif untuk pelajar/mahasiswa 
Tabel 11. Tarif trayek Karpan

\begin{tabular}{|c|c|c|c|c|c|c|c|c|c|}
\hline \multirow{2}{*}{ No } & \multirow{2}{*}{$\begin{array}{l}\text { Nama } \\
\text { Trayek }\end{array}$} & \multirow{2}{*}{\multicolumn{2}{|c|}{ Tarif Pokok }} & \multirow{2}{*}{ Tarif BEP } & \multirow{2}{*}{ Tarif } & \multicolumn{2}{|c|}{ Masyarakat } & \multicolumn{2}{|c|}{ Mahasiswa } \\
\hline & & & & & & Batas Atas & Batas Bawah & Batas Atas & Batas Bawah \\
\hline 1 & Karpan & $\mathrm{Rp}$ & 952 & Rp 4.282 & $\mathrm{Rp} 4.282$ & $\mathrm{Rp} 5.139$ & $\mathrm{Rp} 3.426$ & $\mathrm{Rp} 2.569$ & $\mathrm{Rp} 1.713$ \\
\hline
\end{tabular}

Tarif hasil perhitungan sesuai SK Nomor K.687/AJ.206/DRJD/2002 adalah Rp 4.282- per penumpang-km. Tarif tersebut merupakan tarif Break Even Point (BEP) yang diambah $10 \%$ dari tarif BEP sehingga kelebihan 10\% dianggap sebagai keuntungan operator. Oleh karena itu, tarif batas atas dan batas bawah untuk penumpang umum $\mathrm{Rp}$ 5.139,-, 3.428,-, sedangkan untuk mahasiswa batas atas dan bawah berkisar Rp 2.569-, 1.713,-. Dengan demikian hasil rekapan Analiis BOK dapat dilihat pada Gambar 6 dan 7.

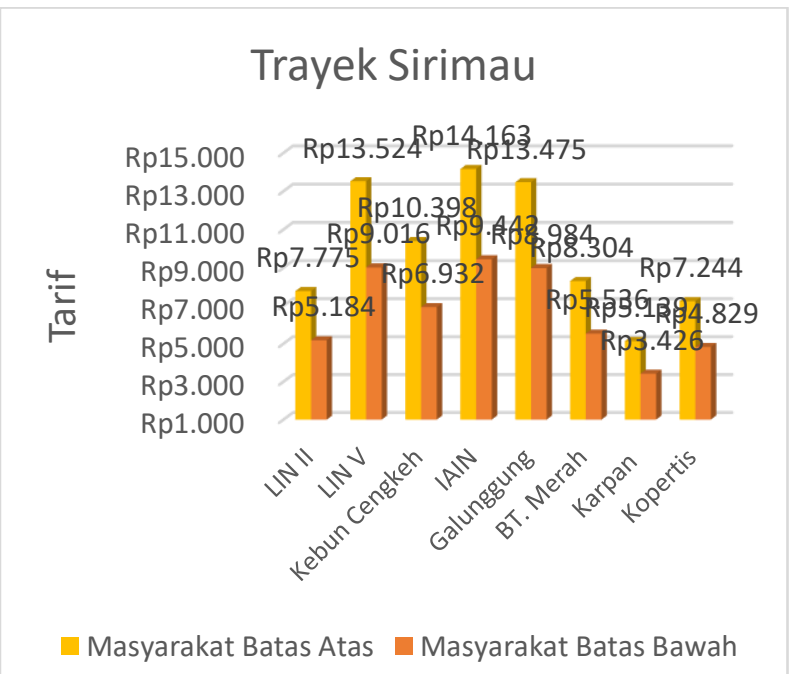

Gambar 6. Grafik rekapitulasi tarif untuk masyarakat

\section{Trayek Sirimau}

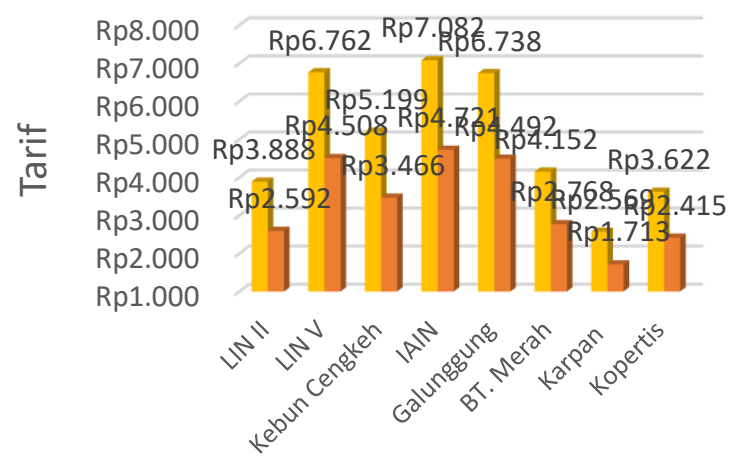

- Mahasiswa Batas Atas Mahasiswa Batas Bawah

Gambar 7. Grafik rekapitulasi Tarif untuk Pelajar/Mahasiswa

\section{KESIMPULAN}

Berdasarkan hasil Analis perhitungan BOK angkutan umum di Kota Ambon. Sesuai dengan Keputusan Direktur Jenderal Nomor SK.687/AJ.206/DRJD/2002 tarif yang dihasilkan adalah Didapat biaya Tarif untuk masyarakat batas atas dan bawah Kecamatan Nusaniwe Rp 16.592 Rp 11.061,- Kecamatan Sirimau Rp 5.138 - Rp 3.425,- Kecamatan Baguala dan Teluk Ambon Rp 25.000 - Rp 16.666,- dan Tarif untuk mahasiswa batas atas dan bawah Kecamatan Nusaniwe Rp 8.296 - Rp 5.531,- Kecamatan Sirimau Rp 2.569 Rp 1.712,- Kecamatan Baguala dan Teluk Ambon Rp 12.500 - Rp 8.333,- Tarif berdasarkan BOK pada masa pemberlakuan Pembatasan Sosial Berskala Besar sangat berbanting terbalik dimana tarifnya antara Rp 25.000 - 5.138,- sedangkan kondisi yang ada dilapangan dimana untuk tarif rill Rp 3.000 - Rp 5.000..

\section{DAFTAR PUSTAKA}

[1] Peraturan Wali Kota Ambon, "PERWALI Nomor 18 Tahun 2020 Tentang Pembatasan Sosial Berskala Besar.” Ambon, 2020.

[2] Departemen Perhubungan RI, "Pedoman Teknis Penyelenggaraan Angkutan Penumpang Umum di Wilayah Perkotaan dalam Trayek Tetap dan Teratur," Keputusan Direktur Jenderal Perhubungan Darat, no. SK.687/AJ.206/DRJD/2002. pp. 2-69, 2002, [Online]. Available: http://hubdat.dephub.go.id/keputusandirjen/tahun-2002/423-sk-dirjen-no-687aj.

[3] F. Miro, Pengantar Sistem Transportasi. Jakarta: Erlangga, 2012.

[4] O. Taming Z., Perencanaan, Pemodelan, Dan Rekayasa TransprtasI, Edisi 2. Bandung: ITB, 2009.

[5] E. K. Murlock, Pengantar Teknik dan perencanaan Transportasi, Erlangga. Jakarta: Erlangga, 1995.

[6] Rahardjo Adisasmita, Dasar-dasar Ekonomi Transportasi. Graha Ilmu, Pertama. Jakarta: Graha Ilmu, 2010.

[7] M. S. Marsy, Ekonomi Transportasi. Jakarta: Ghalia Indonesia, 2003.

[8] J. H. Frans, Y. A. Messah, and N. Issu, "Kajian Tarif Angkutan Umum berdasarkan Biaya Operasional Kendaraan (BOK), 
Ability To Pay (ATP) dan Willingness To

Pay (WTP) di Kabupaten TTS," J. Tek. Sipil, vol. 5, no. 2, pp. 185-198, 2016.

[9] R. Safitri, "Evaluasi Tarif Angkutan Umum Berdasarkan Ability To Pay (ATP) Dan Willingness To Pay (WTP) Di Kota Pangkalpinang," Fropil, vol. 4, no. 2, pp. 156-164, 2016, [Online]. Available: https://journal.ubb.ac.id/index.php/fropil/arti cle/view/1245/882.

[10] E. Jalil, R. Anggraini, and S. Sugiarto, "Analisis Biaya Operasional Kendaraan, Ability To Pay Dan Willingness To Pay Untuk Penentuan Tarif Bus Trans Koetaradja Koridor Iii," J. Arsip Rekayasa Sipil dan Perenc., vol. 1, no. 4, pp. 1-10, 2018, doi: 10.24815/jarsp.v1i4.12449. 